\title{
Effects of seed sources and shade on vigor of Brant's oak seedling
}

\section{Mansour Taghvaei *}

Department of Desert Region Managment, College of Agriculture, Shiraz University, Shiraz 7144165186, Iran

The use of local seed provenance is often recommended in forest restoration. Early vigor is a combination of the performance of seed germination and emergence after planting. The ability of young Brant's oak plants to grow and develop after emergence and its dependence on local habitat conditions was investigated in this study. The effects of seed source and shade on early growing seedlings of Brant's oak (Quercus brantii L.) were determined in field measurements. Seeds of Quercus brantii L. were collected from 4 forest areas (seed sources) in southern Zagros (Provinces of KohkilouyehBouyer Ahmad and Fars) at altitudes of 850, 1,100, 1,500, 2,100 m a.s.l., and planted in a nursery constructed in southwestern Iran. According to a split-plot design consisting of four blocks, each containing two main treatment plots (no shading, partial shading), each main plot was sub-divided into four sub-plots (for elevations of 850, 1,100, 1,500 and $2,100 \mathrm{~m}$ ). Results showed that shade treatments had significant effects on emergence percentage and rate, shoot length, shoot dry weight (SDW), root dry weight (RDW), leaf area (LA), and chlorophyll content. Ecological factors also had an effect on seed performance. Altitude of seed source had a very significant effect on root length, LA, SDW, and RDW. The seeds collected from $850 \mathrm{~m}$ a.s.l. elevation showed the highest performance, especially in leaf area, root length, shoot dry weight, and root dry weight. Our results showed that the altitude of $850 \mathrm{~m}$ a.s.l. was the best for collecting Brant's oak seeds.

Key words: altitude, Brant's oak (Quercus brantii L.), emergence percentage, Iran, root, seed source, shading, shoot

\section{INTRODUCTION}

Approximately $60 \%$ of Iran is classified as arid and semi-arid. Much of the country has a desert climate, with an average annual precipitation of less than $300 \mathrm{~mm}$ (Mansoory 1992). The zagros forests of Iran are classified as semi-Mediterranean forests because of their geographic location and the effects of Mediterranean climate on it. Zagros mountains are the original source of Quercus libani and Q. boissieri. Brant's oak (Quercus brantii L.) is one of the most important deciduous tree species of dry forests in Iran (Zohary 1973). The annual precipitation of the zagros range of the Fars-Zagrosian Brant's oak forest varies from about 400-800 mm, falling mostly in the winter and spring (McGinley 2008). The climate is harsh, with very cold winters and hot dry summers. Four or more months of the year have mean minimum temperatures below $0^{\circ} \mathrm{C}$. Human activities and domestic animals have affected dry forests, severely limiting tree growth, and reducing the extent of these forests by cutting and grazing (El-Moslimany 1986).

Brant's oak only regenerates by seed. Seed quality is also critical for the early vigor of a new plant. Early vigor is a combination of the ability of the seed to germinate and emerge after planting, and the ability of the young plant to grow and develop after emergence (Jin and Wang 2002). Seed and uniformity of germination are limiting factors in forest trees (Fenner 1992). Seed germina- (c) This is an Open Access article distributed under the terms of the Creative Commons Attribution Non-Commercial License (http://creativecommons.org/licenses/by-nc/3.0/) which permits unrestricted non-commercial use, distribution, and reproduction in any medium, provided the original work is properly cited.
Received 22 April 2010, Accepted 01 October 2010

*Corresponding Author

E-mail: taghvaei@shirazu.ac.ir Tel: +98-711-613-8163 
tion plays an important role in the regeneration of plant species, especially under unpredictable environmental conditions like those in Mediterranean ecosystems (Giménez-Benavides et al. 2005). Poor germination and seedling establishment are regarded as the major causes of low densities in Mediterranean forests (Close and Wilson 2002). Seed performance also depends on vigor (Copeland and McDonald 1995). Seed vigor can be affected by provenance or by environmental factors operating during development and maturation, such as seed germination, seedling establishment, and survival regulated by light, climate, edaphicity, and species-specific factors (Taghvaei 2006, Liu et al. 2008).

Environmental factors such as temperature affect germinability of seeds of many species during seed maturation (Pourrat and Jacques 1975). In different plant species, even small differences in temperature during plant development or seed maturation can influence the germinability of seeds (Gutterman 1996). Light quality affect on germinability during seed filling too. Altitude can also influence germinability of seeds; the higher the altitude of seeds, the lower their rate of germination is (Dorne 1981). Seed provenance affects the seed germination, seedling survival, and growth of Prosopis cineraria L. (Arya et al. 1995), the growth and flowering of Coreopsis lanceolata and Salvia lyrata (Liu et al. 2008), and the seed germination, vigour index, germination rate index and oil content in sunflowers (Norcini et al. 2001). Thus, any study of forest restoration should ideally separate the effects of individual environmental factors from their interactions with demographic stages. Early growth stage is an important stage, affected by environmental factors during seed germination and emergence. Germination percentage, time-to-germination, seedling survival, height, flushing, and number of secondary branches of Abies guatemalensis (Rehder), show significant differences among provenances (Andersen et al. 2008).

In tropical dry forests, germination, survival, and seedling growth are affected by light intensity (Khurana and Singh 2001). The reflex of germination to light in- tensity depends on the species and environment. Biomass production, relative growth rate, root/shoot ratio, specific leaf area (LA), net assimilation rate, and LA ratio can be limited by either poor light availability (Rincón and Huante 1993) or low soil moisture due to water use by nurse trees (Rodríguez-Calcerrada et al. 2008) in the dry forest understory. The shade protects soil moisture during seed germination in dry forests. Also it has been found that germination success was approximately equal in shaded and un-shaded sites for some species (Ray and Brown 1995). In dry forests, species germination and early establishment must occur during the first of the wet season when water is at its most available (Khurana and Singh 2001). The general assumption of this study is that provenance variables are a complex of environmental factors and shade changes in early stages of the life cycle of an acorn seed. The aim of this study was to test whether seed vigor and seedling performance are affected by altitude seed source and shade during seedling establishment.

\section{MATERIALS AND METHODS}

\section{Plant material}

Seed lots of Brant's oak (Quercus brantii Lindl.) were collected from 4 forest habitats (seed sources) in southern Zagros (Provinces of Kohkilouyeh-Bouyer Ahmad and Fars), located at elevations of 850, 1,100, 1,500, and $2,100 \mathrm{~m}$ a.s.l. in Iran. After collection, acorns were stored within bags in a refrigerator $\left(5^{\circ} \mathrm{C}\right)$ until the start of each experiment.

\section{Experimental design}

The experiment was set up within an intact area of the College of Agriculture (Badjgah 29 $9^{\circ} 50^{\prime} \mathrm{N}, 52^{\circ} 46^{\prime} \mathrm{E}$ ) at Shiraz University, located at an elevation of 1,810 m a.s.l. in the southwest of Iran (Table 1). The experimental de-

Table 1. Average of maximum, minimum of temperature and monthly of total of precipitation of Badjgah

\begin{tabular}{lcccccccccccc}
\hline & Jan & Feb & Mar & Apr & May & Jun & Jul & Aug & Sep & Oct & Nov & Dec \\
\hline $\begin{array}{l}\text { Maximum } \\
\text { temperature }\left({ }^{\circ} \mathrm{C}\right)\end{array}$ & 12.84 & 12.81 & 16.47 & 23.91 & 27.83 & 34.09 & 35.61 & 35.08 & 32.10 & 28.58 & 19.14 & 13.58 \\
$\begin{array}{l}\text { Minimum } \\
\text { temperature }\left({ }^{\circ} \mathrm{C}\right)\end{array}$ & -5.79 & -2.67 & 1.49 & 4 & 6.75 & 10.75 & 14.52 & 14.36 & 10.47 & 5.05 & 3.21 & -3.36 \\
\begin{tabular}{l} 
Precipitation $(\mathrm{mm})$ \\
\hline
\end{tabular} & 0.68 & 1.05 & 0.77 & 0.11 & 0.00 & 0.00 & 0.00 & 0.00 & 0.00 & 0.00 & 1.40 & 0.42 \\
\hline
\end{tabular}


sign was a split plot one based on a complete randomized block with four blocks: two light levels (no shading, partial shading) were assigned to the main plots, while four seed source sites (altitudes of 850, 1,100, 1,500, 2,100 $\mathrm{m}$ a.s.l.) were assigned to the sub plots. There were two types of shade: no shade (full sunlight) and $50 \%$ shade by shade cloth. The shade used after seed planting to final experiment.

To determine the effects of provenance and light on the germination of seeds and the early establishment of seedlings, the seeds from each treatment were planted in a 0.5 -L plastic pot filled with $500 \mathrm{~g}$ of sandy loam soil. The pots were watered weekly with sufficient water. Emerging seedlings were counted every three days, continuing until when no further germination was recorded, and then vigor-related traits were measured on individual plants after five months. The traits were: emergence percentage (EP), shoot length (SL), and root length (RL). Chlorophyll content (CC) was recorded using the lowest seedling leaf fully expanded from the top of the main stem for each pot at 10:00-12:00 a.m. by a SPAD chlorophyll meter (Minolta SPAD-520; Minotal, Ramsey, NJ, USA) by LA $\left(\mathrm{cm}^{2}\right)$ at the end of this period. LA was measured on collected leaves of the shoot with a LA meter, model MK2 (DeltaT Co., Cambridge, UK). SL was measured by the length from the top to the shoot, and RL was measured by the length from the top of the root. Shoot dry weight (SDW) and root dry weight (RDW) were measured after drying for $24 \mathrm{~h}$ in an oven at $70^{\circ} \mathrm{C}$ (ISTA 1999). Mean time of emergence (MTE) and emergence rate (ER) were calculated for each treatment according to the equations of Ellis and Roberts (1981) and Agrawal and Dadlani (1992) as follows, respectively:

$$
\begin{aligned}
\mathrm{MTE} & =\sum(\mathrm{ni} . \mathrm{ti}) / \sum \mathrm{n} \\
\mathrm{ER} & =\sum(\mathrm{ni} / \mathrm{ti})
\end{aligned}
$$

MTE: mean time to full emergence

ER: emergence rate

Where ni is the number of emerged seeds per day, ti is the amount of time counted from the beginning of emergence. CC was measured on the lowest seedling leaves with a Minolta chlorophyll meter.

\section{Data analyses}

Data were checked for normality, and then were analyzed using MSTATC statistical software (MStat Inc., East Lansing, MI, USA). Treatment means were separated by a Duncan test if the F-value of the treatment was significant at the 0.05 or 0.01 probability levels.

\section{RESULT}

\section{Emergence percentage (EP)}

EPs were significantly different between light treatments $(P<0.05)$ but not between seed sources or sites (Table 2). The mean EPs were $88 \%$ and $65 \%$ in light and shade respectively (Fig. 1). In treatments of all altitudes, shade treatment decreased the EP. The highest seed EP (96\%) was obtained at an altitude of $850 \mathrm{~m}$ above sea level. Seed emergence decreased as the altitude increased (Fig. 1).

\section{Emergence rate (ER)}

There were significant differences in ERs between light treatments $(P<0.01)$ (Table 2). The mean ERs were 4.61 and 1.86 in light and shade, respectively (Fig. 2). There was no significant difference in ER between seed sources

Table 2. Analysis of variance for seed and seedling parameters

\begin{tabular}{lcccccccccr}
\hline Source & $\begin{array}{c}\text { Degrees of } \\
\text { freedom }\end{array}$ & EP & ER & MTE & SL & RL & RDW & SDW & LA & CC \\
\hline Replication & 1 & 153.78 & 3.88 & 1.88 & 4.39 & 3.44 & 0.029 & 0.021 & 115.17 & 5.72 \\
Shade (A) & 3 & $2317.61^{*}$ & $50.73^{* *}$ & 7.84 & $433.72^{* *}$ & 27.67 & $0.69^{*}$ & $0.25^{*}$ & $351.85^{*}$ & $250.26^{*}$ \\
Error & 3 & 116.36 & 1.24 & 1.32 & 3.04 & 11 & 0.06 & 0.007 & 25.83 & 16.08 \\
Seed source (B) & 3 & $387.20^{*}$ & $1.18^{*}$ & 6.10 & 10.21 & $23.22^{*}$ & $0.41^{*}$ & $0.21^{*}$ & 648.17 & 23.48 \\
A*B & 3 & 968.67 & 3.27 & 8.66 & 0.983 & 1.37 & 0.053 & 0.01 & $57.95^{*}$ & 12.57 \\
Error & 18 & 228.59 & 0.80 & 4.71 & 8.05 & 1.731 & 0.05 & 0.015 & 143.74 & 12.25 \\
\hline
\end{tabular}

" and ${ }^{* *}$ indicate significance of $P<0.05$ an $P<0.01$, respectively.

EP, emergence percentage; ER, emergence rate (per day); MTE, mean time emergence; SL, shoot length ( $\mathrm{cm}$ ); RL, root length ( $\mathrm{cm}$ ); RDW, root dry weight (g); SDW, shoot dry weight (g); LA, leaf area $\left(\mathrm{cm}^{2}\right)$; CC, chlorophyll content (spad). 


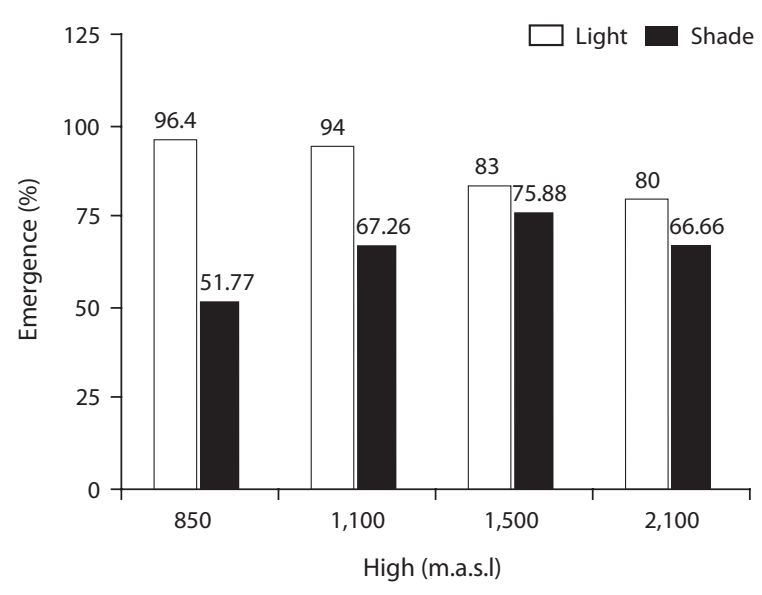

Fig. 1. Emergence percentage of Quercus brantii L. as affected by seed source and light density.

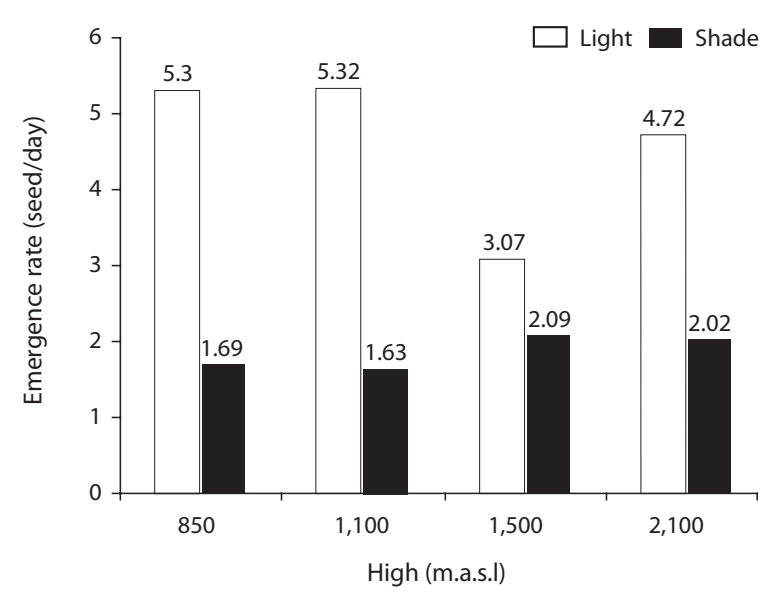

Fig. 2. Emergence rate of Quercus brantii L. as affected by seed source and light density.

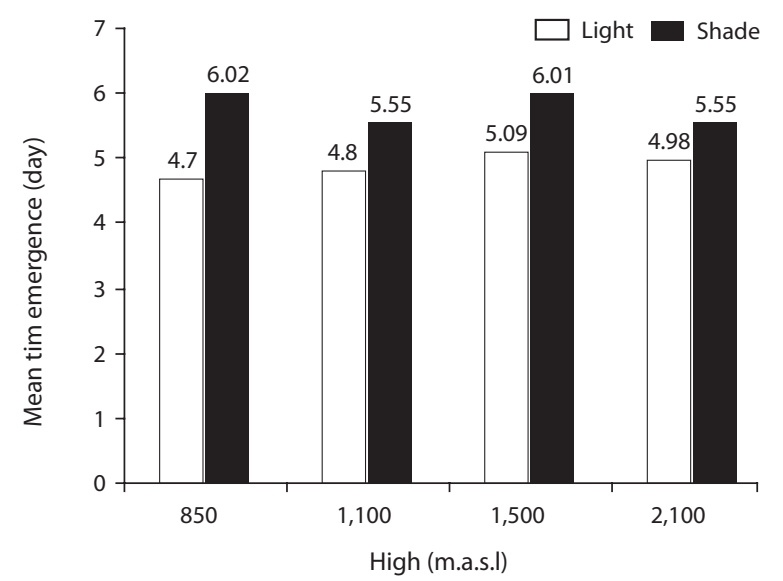

Fig. 3. Mean time emergence rate of Quercus brantii L. as affected by seed source and light density.

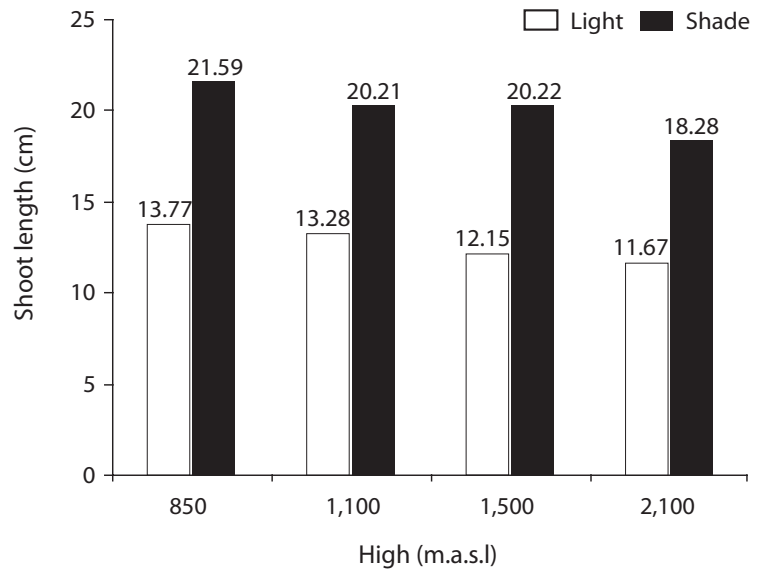

Fig. 4. Shoot length of Quercus brantii L. as affected by seed source and light density.

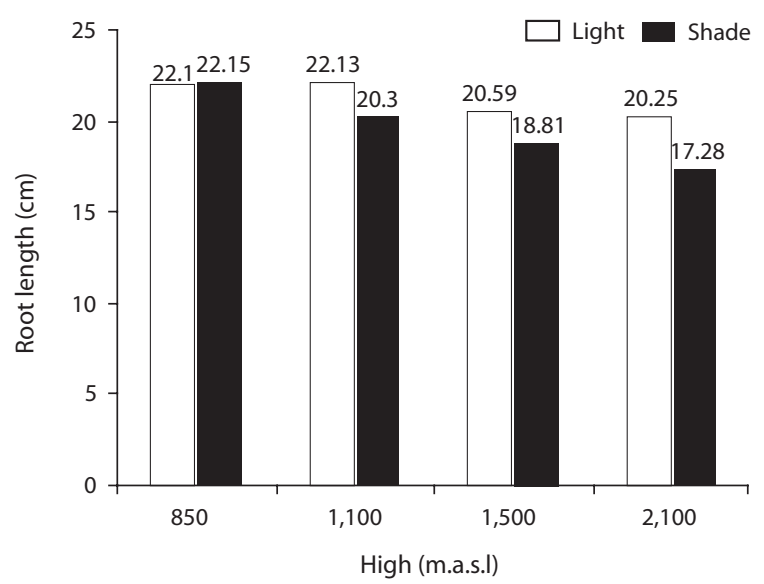

Fig. 5. Root length of Quercus brantii L. as affected by seed source and light density.

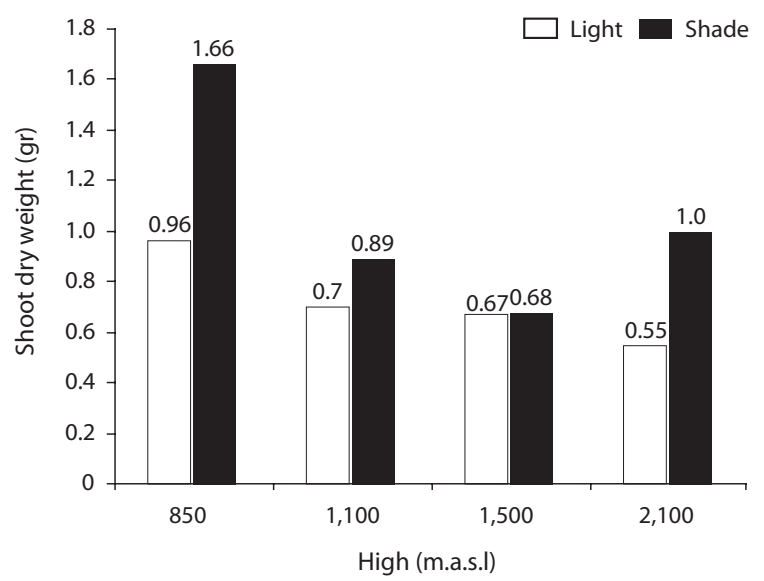

Fig. 6. Shoot dry weight of Quercus brantii L. as affected by seed source and light density. 


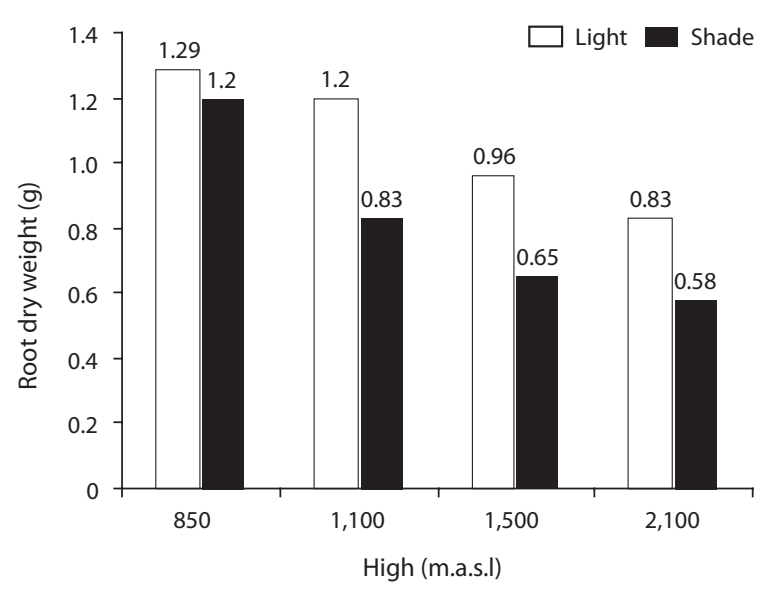

Fig. 7. Root dry weight of Quercus brantii L. as affected by seed source and light density.

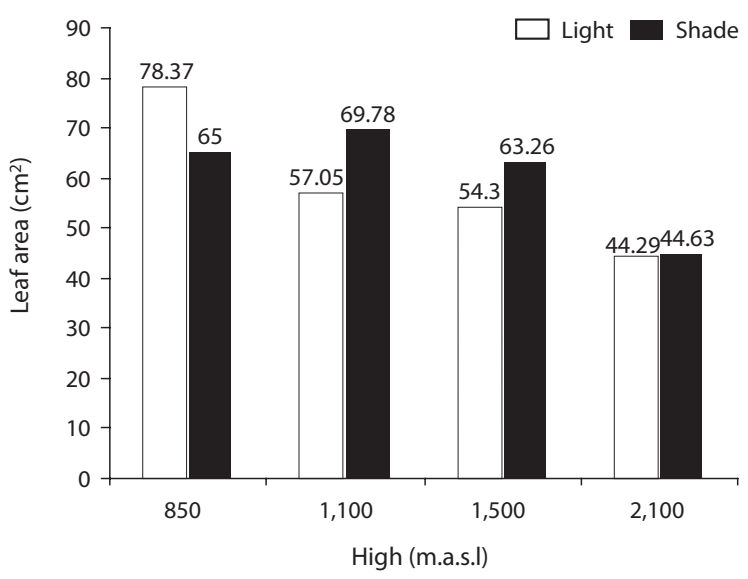

Fig. 8. Leaf area of Quercus brantii L. as affected by seed source and light density.

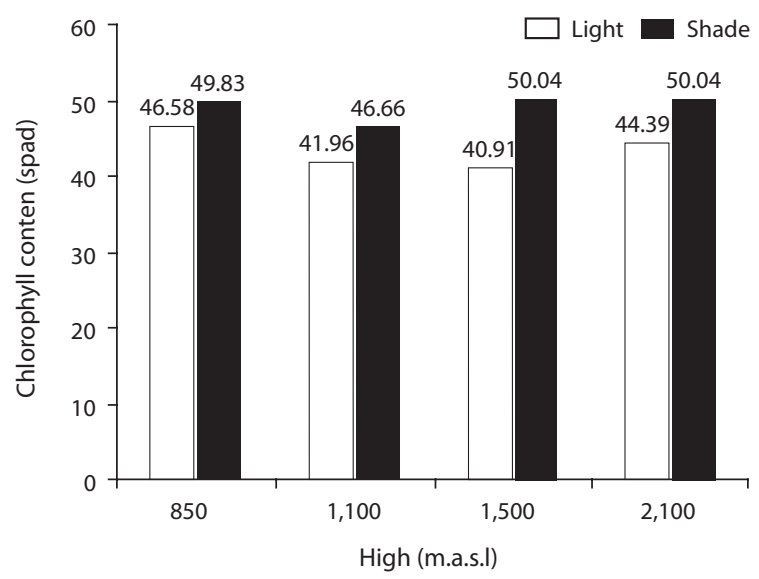

Fig. 9. Chlorophyll content of Quercus brantii L. as affected by seed source and light density. or sites, but the highest seed ER (5.32) was obtained for altitudes of 850 and 1,100 $\mathrm{m}$ above sea level (Fig. 2).

\section{Mean time of emergence (MTE)}

There were significant differences in MTE between light treatments $(P<0.05)$ (Table 2$)$. The shade treatment had a longer MTE than light. The MTE were 4.9 and 5.78 days in light and shade, respectively (Fig. 3). There was no significant difference in MTE between seed sources or sites, but the lowest MTE (4.7 days) was obtained at an altitude of $850 \mathrm{~m}$ above sea level (Fig. 3).

\section{Shoot length (SL)}

SLs were significantly affected by light treatment $(P$ $>0.01$ ) (Table 2) but not by seed sources or sites. Shade treatment increased SL in all treatments. SLs were 12.71 $\mathrm{cm}$ and $20.08 \mathrm{~cm}$ in light and shade, respectively (Fig. 4).

\section{Root length $(\mathrm{RL})$}

There were significant differences in RLs between site treatments $(P<0.01)$, but not between light treatments (Table 1). However, the light treatments had a longer RL than shade (Fig. 5). The longest RL was produced by seeds that were collected at altitudes of 850 and 1,100 m above sea level (Fig. 5).

\section{Shoot and root dry weights (SRDWs)}

SRDWs were significantly affected by light $(P>0.05)$ as well as seed sources and sites $(P>0.01)$ (Table 2). Shade treatment increased SDW significantly in all treatments $(P>0.05)$. SDWs were $0.91 \mathrm{~g}$ and $0.73 \mathrm{~g}$ in light and shade, respectively (Table 2). RDW in light was significantly higher than shade treatment (Fig. 6). RDWs were $1.07 \mathrm{~g}$ and $0.81 \mathrm{~g}$ in light and shade, respectively (Fig. 6). The highest root and shoot weights were produced by seed that collected at an altitude of $850 \mathrm{~m}$ above sea level (Figs. 6 and 7).

\section{Leaf area (LA)}

There were significant differences in leaf areas between light treatments $(P<0.05)$ (Table 2). The leaf areas were 58.5 and $60.86 \mathrm{~cm}^{2}$ in light and shade respectively (Fig. 8). There was no significant difference in LA between seed sources or sites. But the highest LA $\left(72.07 \mathrm{~cm}^{2}\right)$ was obtained in the altitude of $850 \mathrm{~m}$ above sea level (Fig. 8). 


\section{Chlorophyll content (CC)}

CC differed significantly between light treatments $(P<$ 0.05 ), but not between seed sources or sites (Table 2). CCs were 43.46 SPAD and 49.04 SPAD in light and shade, respectively (Fig. 9). Shade treatment increased the CC for treatments at all altitudes (Fig. 9).

\section{DISCUSSION}

\section{Seed source}

Source variation tests is one of method to screen the naturally available genetic variation to select the best planting material for higher productivity (Bhat and Chauhan 2002). The seed may respond to changes in environment (Egli 1998). This study has revealed that the present provenance is a factor controlling the performance of Quercus brantii L. Seeds. The highest seed EP and ER were obtained at an altitude of $850 \mathrm{~m}$ above sea level, and both of them decreased as the altitude increased. Shivanna et al. (2007) reported significant differences among seed sources in seed germination and seeding traits. Latitudinal differentiation on growth characteristics has also been observed in a number of studies on conifers (Wright 1976, Hansen et al. 2004). Therefore, alternation of provenance altitude was found to be an effective factor on seedling parameters. Increase of altitude above sea level decrease seed vigor (EP and ER) and seedling performance (LA, CC, RL, SL, SRDW, etc.). Our results detected that seedling growth decreases with increasing altitude, and that higher altitudes have lower emergence, ER, RL, SL, SRDW, and LA. A similar trend of decreasing seedling growth with increasing altitude has been detected in provenance tests of Abies species (Bongarten and Hanover 1986), but Krishan and Toky (1996) reported that there was no significant relationship between Acacia nilotica ssp. indica seed germination and seedling growth with the latitude or longitude of the original seed source. Jin and Wang (2002) also reported that Bidense pilosa $\mathrm{L}$. var radiate seeds at high altitude showed higher germination percentage, speed of germination, and shorter mean days of germination. Growth season and seed filling duration at low altitudes is longer than at high altitudes; therefore, allowing complete maturation and material translation to seed are necessary for seed vigor (Egli 1998). Early seed vigor is an important trait in forest improvement. Early vigor is a complex of plant performance that is reflected in variations in plant characteristics such as EP, ER, LA, CC, RL, SL, SRDW, etc. (Norcini et al. 2001, Andersen et al. 2008). Seed emergence and seedling performance strategies have important roles in the regeneration of plant species, especially under theunpredictable conditions of Mediterranean ecosystems. So, for dry forest conservation, low altitudes are the best locations for seed harvesting.

\section{Shade treatment}

Forest production differs from in open areas and under forest canopy (Chen et al. 1995). In this experiment, shade treatment had an influence on acorn germination, seedling emergence, and seedling growth. EP, ER, SL, RL, LA, and CC field were significantly affected by light treatments . In general, shade makes for a micro site that may be suitable or not suitable for acorn germination and seedling emergence. Acorns in such sites were protected from humidity and temperature fluctuations (Sarlöv-Herlin and Fry 2000). Shade treatment increased SL, RL, shoot weight, LA, and CC. Factors influencing early survival and growth of seedlings underground may be very different from those determining the growth of older seedlings. Early growth of Brant's oak seedlings under ground in shade or light depend primarily on stored food reserves in the acorns and not on current materials of photosynthetic production (Crow 1988). Once cotyledon reserves are depleted, the growth and survival of seedlings depend on photosynthetic produce generated by new leaves. Light quality then becomes a limiting factor for survival and growth (Crow 1988). Although light is a dominant environmental factor limiting seedling establishment, shade treatment may increase root and shoot growth. Root regeneration and root growth are very sensitive to soil moisture stress (López-Barrera and Newton 2005). In northern red oak, root initiation and growth has been shown to cease at soil osmotic potentials between -0.4 and -0.6 MPa (López-Barrera and Newton 2005). Shade treatment decreased EP and ER. The shade protects soil moisture and decreases soil temperature, so it decreases the field emergence of seeds (Charlton et al. 1986). Additionally, germinated and non-germinated acorns sowed in shade treatments are less damaged by insects compared to light treatments (López-Barrera and Newton 2005). Ray and Brown (1995), however, found that germination success in dry forests in the US Virgin Islands was approximately equal in shaded and unshaded sites. In dry forest, species germination and early establishment must occur during the wet season when water is more available. Therefore, the canopy modifies 
the light quality at the ground level by its filtering influence (Rincón and Huante 1993), and thereby improves survival after emergence in dry seasons (Lieberman and Li 1992).

\section{LITERATURE CITED}

Agrawal PK, Dadlani M. 1992. Techniques in Seed Science and Technololgy. South Asian Publishers, New Delhi.

Andersen US, Prado Córdova JP, Bräuner Nielsen U, Kollmann J. 2008. Provenance variation in germination and seedling growth of Abies guatemalensis Rehder. For Ecol Manag 255: 1831-1840.

Arya S, Toky OP, Bisht RP, Tomar R, Harris PJC. 1995. Provenance variation in seed germination and seedling growth of Prosopis cineraria (L.) Druce in arid India. Silvae Genet 44: 55.

Bhat GS, Chauhan PS. 2002. Provenance variation in seed and seedling traits of Albizzia lebbek Benth. J Tree Sci 21: 52-57.

Bongarten BC, Hanover JW. 1986. Provenance variation in blue spruce (Picea pungens) at eight locations in the northern Unites States and Canada. Silvae Genet 35: 6774.

Charlton JFL, Hampton JG, Scott DJ. 1986. Temperature effects on germination of New Zealand herbage grasses. Proc N Z Grassl Assoc 47: 165-172.

Chen J, Franklin JF, Spies TA. 1995. Growing-season microclimatic gradients from clearcut edges into old-growth Douglas-Fir forests. Ecol Appl 5: 74-86.

Close DC, Wilson SJ. 2002. Provenance effects on pre-germination treatments for Eucalyptus regnans and E. delegatensis seed. For Ecol Manag 170: 299-305.

Copeland LO, McDonald MB. 1995. Principles of Seed Science and Technology. $3^{\text {rd }}$ ed. Kluwer Academic Publishers, Dordrecht.

Crow TR. 1988. Reproductive mode and mechanisms for self-replacement of northern red oak (Quercus rubra): a review. For Sci 34: 19-40.

Dorne AJ. 1981. Variation in seed germination inhibition of Chenopodium bonushenricus in relation to altitude of plant growth. Can J Bot 59: 1893-1901.

Egli DB. 1998. Seed Biology and the Yield of Grain Crops. CAB International, Wallingford.

Ellis RH, Roberts EH. 1981. The quantification of ageing and survival in orthodox seeds. Seed Sci Technol 9: 373-409

El-Moslimany AP. 1986. Ecology and late-Quaternary history of the Kurdo-Zagrosian oak forest near Lake Zeribar, western Iran. Vegetatio 68: 55-63.
Fenner M. 1992. The Ecology of Regeneration in Plant Communities. CAB International, Wallingford.

Giménez-Benavides L, Escudero A, Pérez-García F. 2005. Seed germination of high mountain Mediterranean species: altitudinal, interpopulation and interannual variability. Ecol Res 20: 433-444.

Gutterman Y. 1996. Effect of day length during plant development and caryopsis maturation on flowering and germination, in addition to temperature during day storage and light during wetting, of Schismus arabicus (Poaceae) in the Negev Desert, Israel. J Arid Environ 33: 439-448.

Hansen OK, Nielson UB, Edvardsen OM, Skúlason B, Skage JO. 2004. Nordic provenance trials with Abies lasiocarpa and Abies lasiocarpa var. arizonica: three-year results. Scand J For Res 19: 112-126.

ISTA. 1999. International rules of seed testing. Seed Sci Technol 20: 53-55.

Jin HC, Wang SM. 2002. Effects of water and salt stress on seed germination of Bidens pilosa L. var. radiate Sch. from different sources. Seed Nursery 2: 119-134.

Khurana E, Singh JS. 2001. Ecology of seed and seedling growth for conservation and restoration of tropical dry forest: a review. Environ Conserv 28: 39-52.

Krishan B, Toky OP. 1996. Provenance variation in seed germination and seedling growth of Acacia nilotica ssp. indica in India. Genet Resour Crop Evol 43: 97-101.

Lieberman D, Li M. 1992. Seedling recruitment patterns in a tropical dry forest in Ghana. JVeg Sci 3: 375-382.

Liu X, Khan MA, Tsuji W, Tanaka K. 2008. The effect of light, temperature and bracteoles on germination of polymorphic seeds of Atriplex centralasiatica Iljin under salin conditions. Seed Sci Technol 36: 325-338.

López-Barrera F, Newton A. 2005. Edge type effect on germination of oak tree species in the Highlands of Chiapas, Mexico. For Ecol Manag 217: 67-79.

Mansoory M. 1992. A Directory of Wetland in Middle Est. Ramsar Sites Information Service, Wageningen.

McGinley M. 2008. Zagros mountains forest steppe. In: Encyclopedia of Earth (Cleveland CJ, ed). Environmental Information Coalition, National Council for Science and the Environment, Washington, DC.

Norcini JG, Aldrich JH, Martin FG. 2001. Seed source effects on growth and flowering of Coreopsis lanceolata and Salvia lyrata. J Environ Hortic 19: 212-215.

Pourrat Y, Jacques R. 1975. The influence of photoperiodic conditions received by the mother plant on morphological and physiological characteristics of Chenopodium polyspermum L. seeds. Plant Sci Lett 4: 273-279.

Ray GJ, Brown BJ. 1995. Restoring Caribbean dry forests: 
evaluation of tree propagation techniques. Restor Ecol 3: 86-94.

Rincón E, Huante P. 1993. Growth responses of tropical deciduous tree seedlings to contrasting light conditions. 7 : 202-207.

Rodríguez-Calcerrada J, Pardos JA, Gil L, Aranda I. 2008. Ability to avoid water stress in seedlings of two oak species is lower in a dense forest understory than in a medium canopy gap. For Ecol Manag 255: 421-430.

Sarlöv-Herlin IL, Fry GLA. 2000. Dispersal of woody plants in forest edges and hedgerows in a Southern Swedish agricultural area: the role of site and landscape structure.
Landsc Ecol 15: 229-242.

Shivanna H, Balachandra HC, Suresh NL. 2007. Source variation in seed and seedling traits of Pongamia pinnata. Karnataka J Agric Sci 20: 438-439.

Taghvaei M. 2006. Evaluation of ecophysiological characteristics of barley (Hordeum vulgare L.) seed produced under water stress during seed filling stage. $\mathrm{PhD}$ Dissertation. University of Tehran, Tehran, Iran.

Wright JW. 1976. Introduction to Forest Genetics. Academic Press, New York.

Zohary M. 1973. Geobotanical Foundations of the Middle East. Gustav Fischer Verlag, Stuttgart. 